\title{
Implementasi Model Praktik Keperawatan Profesional Di RSUD Kota Baubau
}

\author{
La ode Syaiful Islamy, Zainul Abidin, Rinita Andriani, Henni Arisanti \\ Program Pascasarjana Universitas Dayanu Ikhsanuddin Baubau \\ Email : syaiful80islamy@gmail.com
}

DOI: https://doi.org/10.33859/dksm.v10i1.388

\begin{abstract}
Abstrak
Latar belakang: Implementasi Model Praktik Keperawatan Profesional (MPKP) di Rumah Sakit bertujuan untuk meningkatkan dan mewujudkan mutu pelayanan keperawatan.

Tujuan: Penelitian ini bertujuan menguraikan bagaimana implementasi kebijakan MPKP di ruang rawat inap RSUD Kota Baubau.

Metode: Desain penelitian yang digunakan adalah penelitian kualitatif dengan pendekatan Studi Kasus.

Hasil: Hasil penelitian menunjukkan dari sisi struktur model praktik keperawatan profesional (MPKP) dari semua tahapan-tahapan model praktik keperawatan profesional (MPKP) yang terlaksana dengan baik hanya pembentukan tim dan Hand Over, sedangkan pre conference, post conference dan ronde keperawatan tidak terlaksana dengan baik. Dari sisi proses implementasi model praktik keperawatan profesional di RSUD Kota Baubau menggunakan metode keperawatan primer modifikasi tim tetapi belum sesuai dengan standar sebab masih terbatasnya sumber daya manusia baik ketua tim maupun anggota yang mempunyai pendidikan Ners yang masih kurang. Dari sisi penerapan nilai-nilai profesional telah dilaksanakan dengan baik seperti memperlakukan pasien dengan baik, keluarga pasien sebagai mitra dan menghargai otonomi pasien

Kata kunci : Implementasi kebijakan, Model Praktik Keperawatan Profesional.
\end{abstract}

\section{Abstract}

Background: The implementation of the Professional Nursing Practice Model (MPKP) at the Hospital

aims: to improve and realize the quality of nursing services. This study aims to describe how the implementation of the MPKP policy in the inpatient ward of Baubau City Hospital.

Method: The research design used was qualitative research with a Case Study approach.

Result: The results showed that in terms of the structure of the professional nursing practice model $(M P K P)$ of all the stages of the professional nursing practice model (MPKP) that were carried out well only team formation and Hand Over, while the pre-conference, post conference and nursing rounds were not well implemented. In terms of the process of implementing the professional nursing practice model in Baubau City Hospital using the team's primary nursing method but not yet in accordance with the standard because there are still limited human resources both team leaders and members who have less Ners education. In terms of the application of professional values, it has been well implemented such as treating patients well, the patient's family as partners and respecting patient autonomy

Keywords: Policy implementation, Professional Nursing Practice Model. 


\section{Pendahuluan}

Perubahan bidang kesehatan di Indonesia saat ini terjadi begitu pesat, persaingan terjadi disemua tatanan kesehatan terutama rumah sakit. Dalam Undang-Undang Nomor 36 Tahun 2009 tentang kesehatan menyatakan bahwa setiap peningkatan mutu pelayanan kesehatan harus disertai dengan peningkatan mutu pelayanan keperawatan. Salah satu kebijakan kesehatan yang merupakan bagian dari kebijakan publik adalah Model Praktik Keperawatan Profesional (Hoffart et al, 1996).

Model Praktik Keperawatan Profesional (MPKP) di Rumah Sakit bertujuan untuk meningkatkan dan mewujudkan mutu pelayanan keperawatan (Sitorus, 2006). Pelayanan keperawatan profesional diberikan dengan berbagai bentuk metode penugasan yang sudah ada dan akan dikembangkan dimasa depan dalam menghadapi tren pelayanan keperawatan. Model Praktek Keperawatan Profesional sendiri adalah sistem yang terdiri dari struktur, proses, dan nilai profesional yang memungkinkan perawat profesional mengatur pemberian Asuhan Keperawatan termasuk lingkungan.

Di berbagai tempat pengembangan MPKP telah terbukti memberikan dampak yang positif bagi pemberian asuhan keperawatan. Hal tersebut sudah dikembangkan di RSUPN Cipto Mangunkusumo Jakarta sejak 1996, dimana dapat meningkatkan mutu asuhan keperawatan dan meningkatan kepatuhan perawat terhadap standar. Model praktik keperawatan profesional (MPKP) di RS Achmad Mochtar Bukittinggi juga telah dilaksanakan mulai Tahun 1999 dan telah dilakukan evaluasi dan diperoleh hasil dimana hasil kepuasan pasien sebelum pelaksanaan MPKP 66,76 \% meningkat menjadi 88,96 \% setelah dilaksanakan MPKP (Sitorus, 2003).

Di Kota Baubau MPKP mulai diimplementasikan sejak 4 Mei 2015 melalui surat keputusan direktur tentang penetapan tim MPKP di RSUD Kota Baubau. Kebijakan tersebut diterbitkan karena keluhan masyarakat terhadap pelayanan keperawatan yang tidak efektif lagi sebab perawat tidak mempunyai pasien kelolaan, kurangnya kolaborasi dengan 
Dinamika Kesehatan Jurnal Kebidanan dan Keperawatan Vol 10 No. 1 Juli 2019 (ISSN: 2086-3454 EISSN: 2549-4058) url: http://ojs.dinamikakesehatan.unism.ac.id DOI : https://doi.org/10.33859/dksm.v10i1 Implementasi Model Praktik Keperawatan Profesional Di RSUD Kota Baubau

tim kesehatan lainnya sehingga kurang dalam memberikan pelayanan kepada pasien. Namun harus diakui bahwa RSUD Kota Baubau selama menerapkan MPKP belum pernah melakukan evaluasi terhadap implementasi MPKP. Kondisi seperti ini bukan hanya terjadi di RSUD Baubau saja namun di beberapa rumah sakit di Indonesia juga belum dievaluasi apakah implementasi MPKP telah sesuai standar MPKP atau tidak, dengan demikian penting dikaji bagaimana model penerapan MPKP tersebut (Pratiwi, 2008).

\section{Metode}

Desain penelitian yang digunakan adalah penelitian kualitatif dengan pendekatan studi kasus. Penelitian ini berfokus pada implementasi MPKP di RSUD Kota Baubau, dimana implementasi kebijakan MPKP sebagai aktivitas (activity) dari Direktur, Kabid Keperawatan, Supervisor dan Kepala ruangan serta Perawat sebagai pelaku (actor), pasien sebagai penerima pelayanan (konsumen) dan RSUD Kota Baubau sebagai tempat (place). Data yang digunakan sebagai dasar untuk menunjang penelitian ini adalah data primer diperoleh dari dua sumber yaitu observasi, dan wawancara. Peneliti melakukan wawancara dengan jajaran manajemen yang terlibat dalam implementasi MPKP RSUD Kota Baubau. Informan ini adalah mereka yang bekerja lingkungan institusi yang menjadi obyek penelitian. Pengamatan partisipatif (observasi) juga dilakukan dengan pengamatan secara langsung aktivitas perawat di RSUD Kota Baubau dalam implementasi kebijakan model praktik keperawatan profesional (MPKP) untuk melengkapi dan mendukung data/informasi yang diperoleh melalui wawancara. Juga dilakukan studi dokumentasi terhadap data-data sekunder tertulis yang bisa menjelaskan lebih rinci terhadap hasil wawancara dan pengamatan tentang implementasi kebijakan MPKP di RSUD Kota Baubau. Teknik analisis data yang digunakan dalam penelitian kualitatif ini adalah mengacu pada konsep Milles \& Huberman dalam Moleong (2010) yaitu interactive model yang mengklasifikasikan analisis data dalam tiga langkah, yaitu reduksi data, penyajian data dan penarikan kesimpulan. 
Hasil

Penelitian ini dilakukan dengan wawancara sebagai sumber utama dimana wawancara dilakukan dari Desember hingga Januari 2019 dengan informan sebanyak 7 orang. Teknik menentukan informan dalam penelitian ini adalah dengan teknik purposive sampling. Informan dalam penelitian ini ada 2 yaitu pertama perawat, dimana informan perawat dalam penelitian ini adalah semua yang terlibat dalam implementasi kebijakan model praktik keperawatan profesional mulai dari manajerial yaitu : kepala bidang keperawatan, supervisor keperawatan dan ruang rawat inap yaitu : kepala ruangan, perawat pelaksana, dengan kriteria perawat dengan masa kerja lebih dari 1 tahun berada di ruangan yang tetap, bersedia di wawancara, tidak sedang dalam masa cuti dan tidak sedang dalam keadaan sakit. Informan dalam penelitian ini selain petugas kesehatan juga pasien sebagai informan yang menerima hasil layanan keperawatan, dengan kriteria pasien yang telah dirawat $\geq 3$ hari, pasien yang mampu berkomunikasi dengan baik dan bersedia untuk diwawancarai.
Hasil wawancara yang dirangkum dan telah diinterpretasi juga dilengkapi hasil observasi dan data dokumentasi

Model praktek keperawatan professional (MPKP) sebagai suatu sistem yang meliputi struktur, proses dan nilai profesional sangat menekankan pada kualitas kinerja tenaga keperawatan yang berfokus pada profesionalisme keperawatan antara lain melalui penetapan dan fungsi setiap jenjang tenaga keperawatan, sistem pengambilan keputusan, sistem penugasan dan sistem penghargaan yang memadai.

\section{Struktur}

Struktur dalam model praktik keperawatan profesional (MPKP) di RSUD Kota Baubau meliputi penetapan jumlah tenaga keperawatan. Jumlah tenaga disini disesuaikan dengan jumlah tempat tidur, berdasarkan permenkes Nomor 129 Tahun 2008 atau berdasarkan tingkat ketergantungan pasien dihitung dengan menggunakan rumus Douglas, penetapan jenis tenaga keperawatan bervariasi dimana standar jenis tenaga kepala ruangan diutamakan Ners, perawat primer juga diutamakan Ners dan 
Dinamika Kesehatan Jurnal Kebidanan dan Keperawatan Vol 10 No. 1 Juli 2019 (ISSN: 2086-3454 EISSN: 2549-4058) url: http://ojs.dinamikakesehatan.unism.ac.id DOI : https://doi.org/10.33859/dksm.v10i1 Implementasi Model Praktik Keperawatan Profesional Di RSUD Kota Baubau

perawat Assosiate adalah D III Keperawatan, hal tersebut tertuang dalam Permenkes Nomor 40 Tahun 2017 dan penetapan standar rencana asuhan keperawatan berpedoman pada standar asuhan keperawatan yang disusun oleh tim penyusun yang terdiri dari bidang keperawatan, komite keperawatan dan kelompok fungsional keperawatan (KFK).

Hasil wawancara dengan beberapa informan menunjukkan bahwa implementasi kebijakan model praktik keperawatan profesional (MPKP) telah ditetapkan sejak Mei 2015. Implementasi model praktik keperawatan profesional (MPKP) di ruang rawat inap telah dilaksanakan walaupun masih terdapat banyak kendala dalam pelaksanaannya. Salah satu kendala dalam implementasi MPKP adalah jumlah tenaga perawat yang kurang, baik dari segi jumlah maupun kualifikasi pendidikan belum memenuhi syarat untuk model praktik keperawatan profesional (MPKP) tetapi karena banyaknya keluhan masyarakat tentang pelayanan keperawatan maka bidang keperawatan berinisiatif untuk melaksanakan model praktik keperawatan profesional (MPKP) di Ruang rawat inap, sehingga merekomendasikan kepada Direktur RSUD Kota Baubau untuk menetapkan kebijakan model praktik keperawatan profesional (MPKP) di ruang rawat inap. Sebelum penetapan implementasi kebijakan model praktik keperawatan profesional (MPKP) di ruang rawat inap telah dilakukan berbagai upaya meliputi pelatihan dan workshop, sosialisasi dan pendampingan oleh tenaga ahli agar semua pihak yang terlibat dalam implementasi model praktik keperawatan profesional (MPKP) paham dan dapat melaksanakan model praktik keperawatan profesional (MPKP) sesuai dengan standar yang ada.

\section{Proses}

Dalam praktik keperawatan profesional metode yang paling memungkinkan pemberian asuhan keperawatan profesional metode yang menggunakan keperawatan primer namun tidak menutup kemungkinan untuk menggunakan metode tim dan metode manajemen kasus atau 
bisa di modifikasi sesuai dengan kondisi

Rumah Sakit.

Berbagai hasil wawancara dengan

informan menunjukkan bahwa proses dalam implementasi model praktik keperawatan profesional di RSUD Kota Baubau menggunakan metode keperawatan primer modifikasi tim. Pemilihan metode ini disesuaikan dengan kondisi tenaga di RSUD Kota Baubau, dimana jumlah tenaga PNS yang kurang dan kualifikasi tenaga yang bervariasi yaitu S2, S1, D3 dan SPK. Di RSUD Kota Baubau metode keperawatan primer modifikasi tim dibagi atas dua tim sesuai dengan jumlah tempat tidur yang ada di ruang rawat inap RSUD Kota Baubau, masing-masing tim dipimpin oleh seorang perawat primer dan perawat assosiate sebagai pelaksana dan bekerjasama merawat pasien. Masing-masing perawat assosiate mempunyai pasien kelolaan yang dirawat bersama dari pasien masuk sampai pulang.

Hal tersebut di atas sesuai dengan standar model praktik keperawatan profesional (MPKP) dan metode keperawatan primer modifikasi tim yang diterapkan di RSUD Kota Baubau ini sesuai pula dengan teori dan telah dicontohkan dibeberapa rumah sakit di Indonesia. Pada model modifikasi ini diberlakukan manajemen sumber daya manusia (SDM), yaitu ada garis koordinasi yang jelas antara perawat primer (PP) dan perawat assosiate (PA). Performa perawat assosiate (PA) dalam satu tim menjadi tanggung jawab perawat primer (PP), dengan demikian perawat primer (PP) adalah seorang manajer asuhan keperawatan. Sebagai seorang manajer perawat primer (PP) harus dibekali dengan kemampuan manajemen dan kepemimpinan sehingga perawat primer (PP) harus memiliki kualifikasi pendidikan S1 Ners dan dapat menjadi manajer dan pemimpin yang efektif di ruang rawat inap untuk kesembuhan dan kepuasan pasien terhadap pelayanan keperawatan yang diberikan.

\section{Nilai-nilai Profesional}

Rumah sakit harus mengutamakan nilainilai profesional dalam memberikan pelayanan kesehatan kepada pasien sebab pasien yang datang ke rumah sakit selain sakit fisik juga ada 
Dinamika Kesehatan Jurnal Kebidanan dan Keperawatan Vol 10 No. 1 Juli 2019 (ISSN: 2086-3454 EISSN: 2549-4058)

url: http://ojs.dinamikakesehatan.unism.ac.id DOI : https://doi.org/10.33859/dksm.v10i1

Implementasi Model Praktik Keperawatan Profesional Di RSUD Kota Baubau

berbagai masalah yang dialami seperti masalah

psikologis, finansial dan lain-lain yang dapat

mempengaruhi kondisi fisiknya sehingga pada

saat berkomunikasi terhadap pasien dan

keluarganya harus menerapkan nilai-nilai

profesional tersebut melalui komunikasi

terapeutik. Nilai-nilai utama yang dimaksud

adalah tentang penghargaan atas otonomi klien,

menghargai klien, melakukan yang terbaik bagi

klien dan tidak merugikan klien.

Hasil wawancara menunjukkan bahwa nilai-nilai profesional seperti : nilai-nilai tentang penghargaan atas otonomi klien, menghargai klien, melakukan yang terbaik bagi klien dan tidak merugikan klien, nilai intelektual, komitmen moral, otonomi, kendali dan tanggung gugat telah dilaksanakan oleh perawat di ruang rawat inap RSUD Kota Baubau. Walaupun kadangkala masih ada keluhan masyarakat terkait penerapan nilainilai profesional ini akibat komunikasi yang tidak baik dari tenaga perawat sehingga dapat terjadi konflik antara perawat, pasien dan keluarganya. Untuk meminimalkan bahkan menghilangkan miskomunikasi tersebut,
RSUD Kota Baubau melalui bidang keperawatan telah melaksanakan pelatihan komunikasi efektif dan excellent service tetapi pada pelatihan tersebut yang dilatih baru sebagian kecil dengan harapan yang sudah dilatih dapat mensosialisasikan kepada perawat yang belum mengikuti pelatihan.

\section{Pembahasan}

\section{Struktur}

Dalam implementasi MPKP di RSUD Baubau, perhitungan kebutuhan tenaga di ruang rawat inap telah dilakukan oleh supervisor keperawatan dengan melibatkan kepala ruangan untuk menyediakan data tingkat ketergantungan pasien yang sebelumnya telah disosialisasikan kepada semua kepala ruangan dengan cara menganalisa tingkat ketergantungan pasien berdasarkan pedoman pada buku standar tenaga perawat di rumah sakit dan cara menghitung kebutuhan tenaga. Setelah dilakukan perhitungan kebutuhan tenaga berdasarkan kriteria yang telah ditentukan sesuai kondisi RSUD Kota Baubau maka didapatkan hasil jika tenaga sukarela 
masuk perhitungan, kebutuhan tenaga sudah terpenuhi.

Jumlah tenaga perawat berdasarkan kualifikasi pendidikan yaitu : S2 Keperawatan sebanyak 1 orang, S1 Ners sebanyak 26 orang, D3 Keperawatan 68 orang, dan SPK 4 orang. Jumlah tenaga perawat berdasarkan status kepegawaian yaitu : PNS 44 orang dan tenaga sukarela 51 orang. Menurut direktorat keperawatan dan keteknisian medik direktorat jenderal pelayanan medik departemen kesehatan Republik Indonesia tentang pedoman standar tenaga keperawatan di Rumah Sakit dinyatakan bahwa kebutuhan tenaga keperawatan ditetapkan berdasarkan karateristik pasien, model penugasan dan kompetensi yang dipersyaratkan untuk mencapai tujuan pelayanan keperawatan dan kualifikasi tenaga perawat berdasarkan kompetensi yang dipersyaratkan untuk mencapai tujuan pelayanan keperawatan.

Penentuan jumlah tenaga di RSUD Kota Baubau berdasarkan tingkat ketergantungan pasien dengan menggunakan rumus Douglas kombinasi Depkes sebab masih banyak Non
Nursing Job yang dilakukan oleh tenaga perawat seperti: kegiatan retur obat, pengawasan keamanan ruang rawat, mengurus pembayaran pasien dan kegiatan lainnya diluar kegiatan keperawatan. Penetapan jenis tenaga keperawatan bervariasi dimana standar jenis tenaga Kepala Ruangan diutamakan Ners, Perawat Primer juga diutamakan Ners dan perawat Assosiate adalah D III Keperawatan, hal tersebut tertuang dalam Permenkes Nomor 40 Tahun 2017. Dalam penerapannya di RSUD Kota Baubau masih ada beberapa kepala ruangan dengan latar belakang pendidikan D III Keperawatan bahkan SPK, begitupun dengan perawat primer masih ada yang mempunyai pendidikan D III Keperawatan hal tersebut dilakukan karena kurangnya tenaga Ners sehingga dalam pelaksanaan model praktik keperawatan profesional (MPKP) kadangkadang terdapat kendala sebab tugas kepala ruangan dan perawat primer/ketua tim tersebut bukanlah tugas yang mudah tetapi membutuhkan ketegasan, knowledge yang baik dan analisa yang baik pula dalam menyusun asuhan keperawatan pasien mulai dari 
Dinamika Kesehatan Jurnal Kebidanan dan Keperawatan Vol 10 No. 1 Juli 2019 (ISSN: 2086-3454 EISSN: 2549-4058) url: http://ojs.dinamikakesehatan.unism.ac.id DOI : https://doi.org/10.33859/dksm.v10i1 Implementasi Model Praktik Keperawatan Profesional Di RSUD Kota Baubau

pengkajian sampai evaluasi dan mampu berkolaborasi dengan tenaga kesehatan lainnya terkait status kesehatan pasien yang menjadi kelolaannya.

Standar asuhan keperawatan (SAK) telah disusun oleh tim berdasarkan 10 penyakit terbesar dan sudah ada format asuhan keperawatan yang terstandar yang memudahkan perawat untuk menulis dan tidak banyak menyita waktu, sebelum implementasi model praktik keperawatan profesional (MPKP) di RSUD Kota Baubau semua perawat menulis asuhan keperawatan dan belum ada format asuhan keperawatan yang terstandar sehingga banyak waktu tersita untuk menulis, tetapi setelah implementasi MPKP telah dikembangkan standar rencana asuhan keperawatan bertujuan mengurangi waktu perawat untuk menulis, sehingga waktu yang tersedia lebih banyak dilakukan untuk melakukan tindakan sesuai kebutuhan pasien. Rencana asuhan keperawatan di validasi oleh perawat primer/ketua tim dan dibahas bersama perawat assosiate dan mengarahkan perawat assosiate pada pelaksanaan tindakan keperawatan pada pasien.

Menurut pengamatan peneliti, jumlah tenaga sudah cukup jika ada tenaga sukarela yang membantu. Perhitungan kebutuhan tenaga di RSUD Kota Baubau berdasarkan tingkat ketergantungan pasien dengan menggunakan rumus Douglas modifikasi Depkes dan kualifikasi pendidikan yang berfariasi yang didominasi oleh pendidikan D III Keperawatan serta masih ada pendidikan SPK. Walaupun menurut perhitungan jumlah tenaga cukup tetapi baik tenaga sukarela maupun tenaga PNS tidak disiplin terhadap waktu bekerja, tenaga sukarela yang bekerja di dua tempat sehingga jika masih bekerja ditempat yang lain maka pekerjaan di RSUD Kota Baubau diabaikan, ada tenaga yang tidak maksimal dalam bekerja disebabkan karena sakit, dan Non Nursing Job yang membebani perawat sehingga dalam pelaksanaan model praktik keperawatan profesional (MPKP) belum maksimal disebabkan oleh keadaan tenaga perawat tersebut. 
Model praktik keperawatan profesional (MPKP) tetap tidak terlaksana dengan baik, dari semua tahapan-tahapan model praktik keperawatan profesional (MPKP) yang terlaksana dengan baik hanya pembentukan tim dan Hand Over, sedangkan pre conference, post conference dan ronde keperawatan tidak terlaksana dengan baik, selain tidak disiplinnya tenaga perawat juga disebabkan kurang pemahaman tentang model praktik keperawatan profesional (MPKP) sebab yang dilatih hanya terbatas kepala ruangan dan ketua tim. Sosialisasi dan pendampingan oleh tenaga ahli juga belum dilakukan.

\section{Proses}

RSUD Kota Baubau dalam memberikan pelayanan keperawatan memilih metode keperawatan primer modifikasi tim sesuai dengan kondisi RSUD Kota Buabau saat ini. Hal ini mengacu pada standar praktik keperawatan tahun 2005 dimana standar praktik keperawatan merupakan ekspektasi atau harapan-harapan minimal dalam memberikan asuhan keperawatan yang aman, efektif dan etis.
Menurut Sitorus (2006) penetapan sistem model praktik keperawatan profesional (MPKP) metode keperawatan primer modifikasi tim ini didasarkan pada beberapa alasan sebagai berikut :

a) Keperawatan primer tidak digunakan secara murni, karena perawat primer harus mempunyai latar belakang pendidikan S1 Keperawatan (Ners) atau setara.

b) Keperawatan tim tidak digunakan secara murni, karena tanggung jawab asuhan keperawatan pasien terfragmentasi pada berbagai tim.

Melalui kombinasi kedua model tersebut diharapkan komunitas asuhan keperawatan dan akuntabilitas asuhan keperawatan terdapat pada perawat primer (PP), karena saat ini perawat yang ada di RSUD Kota Baubau sebagian besar adalah lulusan DIII Keperawatan bahkan masih ada tenaga perawat dengan pendidikan SPK. Bimbingan tentang asuhan keperawatan diberikan oleh perawat primer atau ketua tim kepada perawat associate, perawat primer juga yang merencanakan untuk semua asuhan keperawatan pasien kelolaannya sehingga 
Dinamika Kesehatan Jurnal Kebidanan dan Keperawatan Vol 10 No. 1 Juli 2019 (ISSN: 2086-3454 EISSN: 2549-4058)

url: http://ojs.dinamikakesehatan.unism.ac.id DOI : https://doi.org/10.33859/dksm.v10i1 Implementasi Model Praktik Keperawatan Profesional Di RSUD Kota Baubau

perawat assosiate tidak banyak waktu tersita untuk menulis tetapi lebih fokus pada perawatan terhadap pasien dan divalidasi oleh perawat primer yang nantinya akan didiskusikan bersama dalam pengambilan keputusan terhadap perawatan pasien yang efektif dan berkualitas. Metode keperawatan primer modifikasi tim ini sebenarnya sudah dikembangkan di RSUPN Cipto Mangunkusumo Jakarta Tahun 1996, manfaat model praktik keperawatan (MPKP) di RSUPN Cipto Mangunkusumo yang dikembangkan adalah diharapkan dapat meningkatkan mutu asuhan keperawatan, dinilai berdasarkan peningkatan kepuasan klien/keluarga, peningkatan kepatuhan perawat terhadap standar, penurunan angka infeksi nosokomial, dan lama hari rawat lebih pendek.

Dari beberapa metode yang ada, institusi pelayanan perlu mempertimbangkan kesesuaian model tersebut untuk diterapkan. Tetapi, setiap unit keperawatan mempunyai upaya untuk menyeleksi model untuk mengelola asuhan keperawatan berdasarkan kesesuaian antara ketenagaan, sarana dan prasarana serta kebijakan rumah sakit.

Berdasarkan hasil pengamatan peneliti bahwa metode keperawatan yang ditetapkan di RSUD adalah metode keperawatan modifikasi tim tetapi belum sesuai dengan standar sebab masih ada kepala ruangan dengan pendidikan $\mathrm{D}$ III Keperawatan yaitu ruang perawatan bedah kelas 1 dan 2 begitupun dengan ketua tim masih ada yang mempunyai pendidikan D III Keperawatan yaitu ruang perawatan interna kelas 3, Ruang perawatan bedah kelas 1 dan 2, ruang perawatan bedah kelas 3. Ketua tim dengan pendidikan D3 Keperawatan yang dipilih berdasarkan pengalaman bekerja, kompeten dalam melakukan tindakan dan dokumentasi asuhan keperawatan. Hal tersebut dilakukan sebab yang mempunyai pendidikan Ners masih kurang dan ada yang berpendidikan Ners tetapi tidak kompeten, artinya pengalaman kerja belum ada, jenjang karir masih PK 1 (Perawat Klinis 1), sedangkan yang dipersyaratkan sebagai ketua tim adalah PK 3 (Perawat Klinis 3) dengan masa kerja di atas 10 
Tahun untuk D III Keperawatan dan diatas 7 tahun untuk Ners.

Kebutuhan tenaga dimasing-masing unit rawat inap sudah disesuaikan dengan penggunaan bed dan tingkat ketergantungan pasien, namun jika hanya tenaga PNS dinyatakan masih kurang tetapi jika ada tenaga sukarela yang membantu melaksanakan proses keperawatan maka tenaga yang ada sudah cukup. Proses keperawatan yang dilakukan mulai dari pengkajian sampai dengan evaluasi masih ada beberapa ruangan yang belum sesuai dengan standar pendokumentasiannya, hal tersebut disebabkan oleh kurangnya pengetahuan dan beban kerja yang berlebihan dimana perawat masih mengerjakan tugastugas administrasi dan tugas lainnya (Non Nursing Job). Dengan semakin meningkatnya kebutuhan masyarakat akan pelayanan keperawatan dan tuntutan perkembangan IPTEK, maka metode sistem pemberian asuhan keperawatan harus efektif dan efisien.

\section{Nilai}

Perawat memperoleh nilai-nilai profesional ketika ia bersosialisasi dengan pasien, keluarga pasien, seprofesi maupun dengan profesi kesehatan lainnya dalam pelaksanaan asuhan keperawatan, selain itu dapat pula diperoleh dari kode etik, pengalaman merawat, pendidik/pembimbing dan sesama perawat. Untuk mengasah nilai-nilai profesional tersebut tenaga perawat harus sering mendapatkan pendidikan dan pelatihan walaupun hanya dari kepala ruangan atau perawat primer yang bertanggung jawab terhadap terlaksananya asuhan keperawatan di ruang rawat inap. Kepala ruangan harus melakukan supervisi terhadap perawat primer/ketua tim dalam melaksanakan asuhan keperawatan begitupun dengan perawat primer juga harus melakukan supervisi terhadap perawat assosiate sebagai pelaksana perawatan terhadap pasien di ruang rawat inap. Hal tersebut dilakukan agar nilai-nilai profesional tetap terjaga, harus saling mengingatkan antara kepala ruangan dengan perawat primer maupun perawat primer dengan perawat assosiate melalui validasi secara asertif sehingga pelayanan keperawatan yang diberikan bermutu dan profesional tanpa menyinggung 
pihak manapun(Indrawati, 2003). Kualitas asuhan keperawatan yang diberikan kepada pasien sangat dipengaruhi oleh kualitas hubungan perawat-pasien, bila perawat tidak memperhatikan hal ini, hubungan perawat pasien tersebut bukanlah hubungan yang memberi dampak terapeutik yang mempercepat kesembuhan pasien, tetapi hubungan sosial biasa.

Di RSUD Kota Baubau nilai-nilai profesional ini sangat diperhatikan oleh perawat dalam memberikan pelayanan keperawatan kepada pasien, walau dengan berbagai keterbatasan tetap pasien lebih diutamakan dalam pelayanan. Sumjatun (2010) menyatakan kode etik perawat adalah suatu pernyataan atau keyakinan yang mengungkapkan kepedulian moral, nilai dan tujuan model ini, perawat primer dan perawat assosiate membangun kontak dengan klien/keluarga yang merupakan awal dari penghargaan atas harkat dan martabat manusia. Hubungan tim akan terus dibina selama klien dirawat di ruang rawat tersebut sehingga klien/keluarga menjadi mitra dalam memberi asuhan keperawatan.

Menurut hasil pengamatan peneliti bahwa penerapan nilai-nilai profesional telah dilaksanakan dengan baik, semua perawat selalu mengetuk pintu, memberi salam jika masuk ke ruangan pasien, perawat selalu tersenyum jika bertemu dengan pasien dan keluarganya, memperlakukan pasien, keluarga sebagai mitra dan menghargai otonomi pasien sehingga pada saat pelaksanaan tindakan keperawatan melibatkan pasien dan keluarganya. Hal tersebut dilakukan agar pasien merasa dihargai terhadap setiap keputusan yang diambil untuk kesembuhannya, dalam hal ini perawat hanya memberikan penjelasan dan pasien yang akan memutuskan tindakan mana yang harus dilakukan untuk kesembuhannya. Setiap tindakan keperawatan yang diberikan selalu meminta persetujuan pasien dan menjelaskan kepada pasien tujuan dari tindakan yang diberikan. Selanjutnya adalah menghargai klien, di RSUD Kota Baubau dalam melaksanakan asuhan keperawatan, cara berkomunikasi berbeda pada 
saat berkomunikasi dengan pasien dewasa, pasien lansia dan pasien anak begitupun pada saat melakukan tindakan, semunya butuh keterampilan khusus dan pengalaman dalam merawat pasien. Nilai-nilai profesional lainnya adalah melakukan yang terbaik bagi pasien dan tidak merugikan pasien baik dari segi finansial maupun kerugian fisik. Di RSUD Kota Baubau pasien dirawat dengan sebaik mungkin sesuai dengan panduan yang ada dalam clinikal pathway bahwa setiap pasien sudah ada target dalam perawatannya selama berapa hari dilakukan perawatan dan pengobatan dan sudah ada standar prosedur operasional (SOP) untuk setiap tindakan keperawatan yang dilakukan sehingga hal tersebut dapat meminimalkan kerugian finansial maupun fisik terhadap pasien.

Nilai-nilai profesional lainnya yang telah dilakukan di RSUD Kota Baubau adalah komitmen moral, otonomi, kendali dan tanggung gugat. Nilai komitmen moral dalam pelayanan keperawatan diberikan dengan konsep altruistic (mengutamakan kepentingan orang lain) dan memperhatikan kode etik keperawatan. Pelayanan profesional terhadap masyarakat memerlukan integritas, komitmen moral dan tanggung jawab etik. Hal tersebut telah dilaksanakan di RSUD Kota Baubau. Otonomi disini merupakan kebebasan dan kewenangan untuk melakukan tindakan secara mandiri, hal tersebut tertuang dalam rincian kewenangan klinis masing-masing tenaga keperawatan sesuai dengan kompetensinya. Hak otonomi merujuk kepada pengendalian kehidupan diri sendiri yang berarti bahwa perawat memiliki kendali terhadap fungsi mereka. Otonomi melibatkan kemandirian, kesediaan mengambil resiko dan tanggung jawab serta tanggung gugat terhadap tindakannya sendiri. Setiap perawat yang bekerja dilayanan keperawatan RSUD Kota Baubau telah memiliki Surat tanda resistrasi (STR) dan surat izin praktek (SIP), kedua surat tersebut merupakan pegangan yang harus dimiliki oleh seorang perawat padaa saat melakukan tindakan keperawatan.

Nilai-nilai profesional yang belum dilaksanakan di RSUD Kota Baubau adalah tehnik komunikasi yang kurang baik dari 
Dinamika Kesehatan Jurnal Kebidanan dan Keperawatan Vol 10 No. 1 Juli 2019 (ISSN: 2086-3454 EISSN: 2549-4058)

url: http://ojs.dinamikakesehatan.unism.ac.id DOI : https://doi.org/10.33859/dksm.v10i1

Implementasi Model Praktik Keperawatan Profesional Di RSUD Kota Baubau

perawat yang melaksanakan tindakan

keperawatan, kadang-kadang terjadi

miskomunikasi antara perawat dengan pasien

atau keluarganya. Hal tersebut dapat terjadi

sebab pasien yang dirawat di rumah sakit

sebagain besar selain sakit fisik juga sakit

secara psikologis dan keuangan begitupun

dengan perawat dengan beban kerja yang besar

menyebabkan perawat gampang tersinggung

sehingga komunikasi yang diberikan sudah

tidak sesuai dengan standar yang seharusnya

kepada pasien dan keluarganya. Solusi dari

keadaan tersebut adalah dengan melakukan

sosialisasi bagi tenaga perawat yang belum

dilatih oleh tenaga perawat yang telah dilatih

dimasing-masing ruang rawat inap dan

difasilitasi oleh bidang keperawatan RSUD

Kota Baubau.

\section{Kesimpulan}

Hasil penelitian menunjukkan dari sisi struktur model praktik keperawatan profesional (MPKP) dari semua tahapan-tahapan model praktik keperawatan profesional (MPKP) yang terlaksana dengan baik hanya pembentukan tim dan Hand Over, sedangkan pre conference, post conference dan ronde keperawatan tidak terlaksana dengan baik. Dari sisi proses implementasi model praktik keperawatan profesional di RSUD Kota Baubau menggunakan metode keperawatan primer modifikasi tim tetapi belum sesuai dengan standar sebab masih terbatasnya sumberdaya manusia baik ketua tim maupun anggota yang mempunyai pendidikan Ners yang masih kurang. Dari sisi penerapan nilai-nilai profesional telah dilaksanakan dengan baik seperti memperlakukan pasien dengan baik, keluarga pasien sebagai mitra dan menghargai otonomi pasien. Nilai-nilai profesional yang belum dilaksanakan di RSUD Kota Baubau adalah tehnik komunikasi yang kurang baik dari perawat yang melaksanakan tindakan keperawatan, kadang-kadang terjadi miskomunikasi antara perawat dengan pasien atau keluarganya.

\section{Daftar Pustaka}

Direktorat Keperawatan Dan Keteknisian Medik Direktorat Jenderal Pelayanan Medik, 2005, Standar Tenaga Keperawatan Di Rumah Sakit, Departemen Kesehatan RI, Jakarta 
Direktorat Keperawatan Dan Keteknisian Medik Direktorat Jenderal Pelayanan Medik, 2005, Standar Tenaga Keperawatan Di Rumah Sakit, Departemen Kesehatan RI, Jakarta

Hoffart N, Woods C. Elements of a Nursing Professional Practice Model. Journal of Professional Nursing. 1996; Vol 12, No 6 354-64

Indrawati.(2003). Komunikasi Untuk Perawat. Jakarta: EGC

Keputusan Menteri Kesehatan Republik Indonesia Nomor 129 Tahun 2008 tentang Standar Pelayanan Minimal Rumah Sakit.

Moleong, Lexy J. 2010, Metodologi Penelitian Kualitatif PT.Remaja Rosda Karya, Bandung.

Peraturan Menteri Kesehatan Republik Indonesia Nomor 40 Tahun 2017 Tentang Pengembangan Jenjang Karir Profesional Perawat Klinis

Pratiwi, Muhlisin. Kajian Penerapan Model Praktik Keperawatan Profesional (MPKP) Dalam Pemberian Asuhan Keperawatan Di Rumah Sakit. Jurnal Kesehatan 2008;Vol.1, No.1:73-80

Sitorus Ratna, 2003, Dampak Implementasi Model Praktik Keperawatan Profesional Terhadap Mutu Asuhan Keperawatan di Rumah Sakit, https://media.neliti.com/media/publicatio ns/110240-ID-dampak-implementasimodel-praktik-kepera.pdf, akses tanggal 22 Maret 2018.

Sitorus Ratna, 2006, Model Praktik Keperawatan Profesional Di Rumah Sakit, Penerbit Buku Kedokteran EGC, Jakarta
Sumijatun. 2010. Konsep Dasar Menuju Keperawatan Profesional. Jakarta : Trans Info Media

Surat Keputusan Direktur RSUD Kota Baubau Nomor 465/KEP/V/2015 tentang Penetapan Tim MPKP

Undang-Undang Republik Indonesia Nomor 36 Tahun 2009 Tentang Kesehatan 